\title{
A Convex Hull Approach to Counterfactual Analysis of Trade Openness and Growth
}

\author{
MICHAEL FUNKE \\ MARC GRONWALD
}

CESIFO WORKING PAPER NO. 2692

CATEGory 6: FisCAL Policy, MACROECONOMICS AND GROWTH JUNE 2009

An electronic version of the paper may be downloaded

- from the SSRN website:

wWw.SSRN.com

- from the RePEc website:

www.RePEc.org

- from the CESifo website:

www.CESifo-group.org/wp 


\title{
A Convex Hull Approach to Counterfactual Analysis of Trade Openness and Growth
}

\begin{abstract}
In this paper, we apply a convex hull approach to counterfactual analysis of trade openness and growth. The experiments we choose evaluate the importance of trade openness for growth across African countries. Specifically, we ask the question "what would happen if African countries were more open?". The evidence indicates that several countries don't fall within the convex hull of the observed data and therefore counterfactual inferences are risky. This conclusion is at odds with the literature arguing that greater trade openness would unequivocally lead to higher growth in Africa.

JEL Code: O11, O40, C52.

Keywords: openness, economic growth, robustness, counterfactuals, convex hull.

\author{
Michael Funke \\ Department of Economics \\ Hamburg University \\ Von-Melle-Park 5 \\ 20146 Hamburg \\ Germany \\ funke@econ.uni-hamburg.de
}

\author{
Marc Gronwald \\ Ifo Institute for Economic Research at the \\ University of Munich \\ Poschingerstrasse 5 \\ 81679 Munich \\ Germany \\ gronwald@ifo.de
}

Hamburg, Revised June 2009

We would like to thank Athanasios Vamvakidis (IMF) for the use of his data set on openness and growth and participants at the CESifo Money, Macro and Finance Conference for their views and useful discussions on a preliminary draft of the paper. The usual disclaimer applies. 


\section{Introduction}

A common aim of many empirical economic growth studies is to assess whether a pro-openness trade policy has a causal effect on either the growth rate or the level of GDP. A vast amount of literature, for example, has assessed the causes of the East Asian Miracle [World Bank (1993)]. An obvious and salient fact is that these countries experienced an extremely rapid export growth, a feature which can be seen as a critical variable in the economic take-off of the initial NIEs (Korea, Taiwan, Hong Kong and Singapore) since 1960. Subsequently, the second tier of NIEs (Malaysia, Thailand and Indonesia) also experienced rapid growth in the 1980s, to be followed in the 1990s by China. ${ }^{1}$ In many interpretations, this "opening-up" is seen as having provided a key stimulus to set in motion a cumulative process of high investment, high savings, high profits, and high growth. ${ }^{2}$ On the other hand, one has to admit that empirical studies that link "pro-openness" to growth have been plagued by problems of causality, country heterogeneity, and endogeneity. Nevertheless, drawing on the experiences of the NIE's, "pro-openness" is now part of the standard policymaking toolkit recommended to countries wishing to raise their growth rates.

This problem of interference involves "what if" questions and statements and thus counterfactual outcomes. In our specific context, the counterfactual question is as follows: what would the growth rate of some countries in the sample have been, had they decided to liberalise their trade regime in the hope of emulating Asia's success? One may also ask the hypothetical question what would the growth rate of open economies have been, had they decided to close their economies? Given the widespread scepticism regarding the possibility of making sound inference based on cross-country data, we present a first-of-its-kind convex hull analysis within the empirical growth literature evaluating the openness-growth nexus. ${ }^{3}$ In other words, our modest methodological contribution here is to suggest a framework to deal with counterfactual questions in a straightforward manner.

This paper is structured in the following way. In the second Section, we briefly review the principles underlying the convex hull analysis. ${ }^{4}$ In Section 3 we apply the methodology to a dataset which has been used recently in the growth literature and we simulate several counterfactual histories of the

\footnotetext{
${ }^{1}$ Recently, China's export growth has attracted a great deal of attention. How has China achieved this phenomenal export growth? Recent studies highlight the sophistication of Chinese exports, the diversification of its product mix, and the growth in new varieties. Sophistication leads to higher productivity growth and diversification might aid growth by facilitating new export discoveries. See Hausmann and Rodrik (2003), Rodrik (2006) and Schott (2006).

${ }^{2}$ The precise mechanism through which countries commence on a rapid growth path is the subject of much discussion. An important mechanism identified is that pro-openness policies expose firms to foreign competition, technology and can thus lead to productivity gains.

${ }^{3}$ This is not the only way one might assess the counterfactual problem. Billmeier and Nannicini (2007) have recently applied matching estimators drawn from the treatment literature to make the comparison between "open" (i.e. treated) and "closed" (i.e. control) countries. Levine and Renelt (1992) and Temple (2000) have applied extreme-bounds analysis to show that the results of cross-country growth regressions are not robust to even small changes in the set of explanatory variables.
} 
level of selected trade openness variables. In Section 4, we confront the numerical underpinnings with empirical data. Section 5 concludes.

\section{Convex Hull Methodology: A Primer}

This section outlines the dangers of extreme counterfactuals, the resulting model dependence of statistical inference, and how to identify extreme counterfactuals using the convex hull methodology and complementary distance-from-the-data techniques suggested by King and Zeng $(2006,2007){ }^{5}$

Figure 1 illustrates the basic idea using Vamvakidis' (2002) cross-country dataset for the years 1970-1990. ${ }^{6}$ The scatterplot presents each country's trade share against its average real GDP per capita growth rate. The graph vividly illustrates the concept of model dependence and its relation to the distance from the data. It is evident that predictions of the linear, logarithmic, and quadratic models are virtually the same for trade shares up to 0.5 - King and Zeng refer to this as "nearby" the data. However, the farther one drifts away from the data, the larger the difference between the three model's predictions becomes. In other words, it is not the data that drives the results but assumptions regarding the functional form of the relationship. Thus, inference becomes highly model dependent "hazardous", as King and Zeng have phrased it.

Figure 1 illustrates that there is an enormous variation in trade openness and growth rates across countries. It is also apparent that most African countries reside in the lower left part of the graph. In comparison with the rest of the world, as indicated in the graph, they are thus relatively closed. Furthermore, over the period 1970-1990 the African countries exhibit low average growth rates. ${ }^{7}$

\footnotetext{
${ }^{4}$ There is not enough space here in which to provide a complete description of the convex hull methodology and mathematical proofs. Readers interested in detailed descriptions of the methodology are invited to consult textbooks on the subject, including de Berg et al. (2000).

${ }^{5}$ In two recent papers, King and Zeng $(2006,2007)$ have addressed the dangers of extreme counterfactuals in political science. They have exemplified the methodology using two examples. The first evaluates inferences on the effects of democracy. They demonstrate that many counterfactual questions are far from the data and therefore drawing conclusions about the effects of democracy are indefensible. The second example applies the convex hull methodology to studies analysing international peacebuilding strategies. Again, they demonstrate that inferences about the effects of UN interventions are highly sensitive to model specification and robust inferences are unallowable.

${ }^{6}$ For a thorough description of the dataset, see Section 3.

${ }^{7}$ Sub-Saharan Africa has been the slowest growing region in the world. Several African countries have even experienced absolute declines in living standards, i.e. growth disasters. For an analysis of Africa's growth experience, see Easterly and Levine (1997).
} 


\section{Figure 1: Illustrating Model Dependence}

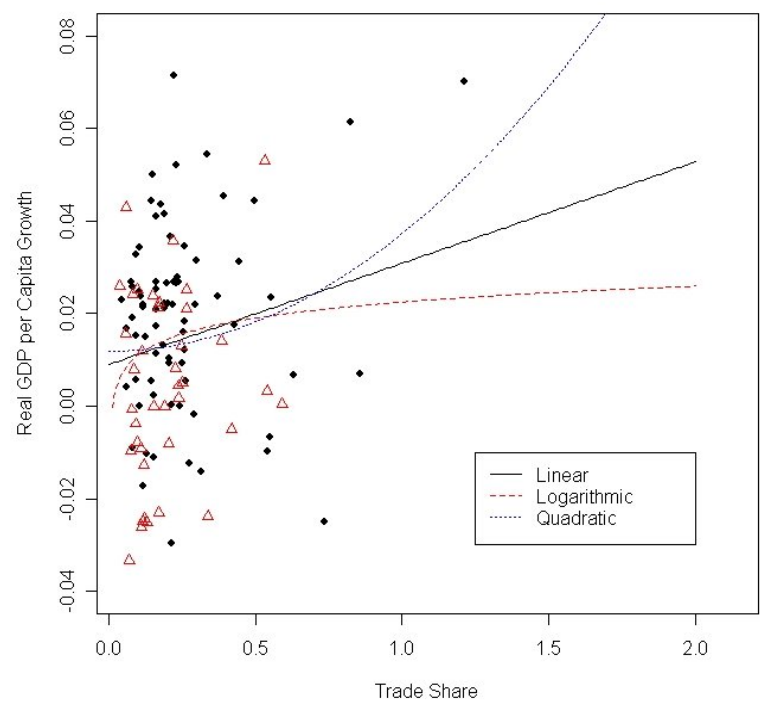

Note: Triangles represent African countries, circles the rest of the world.

However, as is usually the case, reality is more complicated. In the majority of cases, models involve more than one explanatory variable. How can we assess model dependence in multivariate analyses? An answer to this question is provided by the convex hull methodology. In mathematics, a convex hull of a set of points is the smallest convex polygon that contains each of the points. Expressed in clear terms, the convex hull of a set of points $S$ in $n$ dimensions is the intersection of all convex sets containing $S$. For $N$ points $x_{1}, \ldots, x_{N}$, the convex hull $C$ is then given by the expression

$$
C \equiv\left\{\sum_{j=1}^{N} \lambda_{j} x_{j}: \lambda_{j} \geq 0 \text { for all } j \text { and } \sum_{j=1}^{N} \lambda_{j}=1\right\}
$$

The intuition is fairly straightforward. For two explanatory variables, the convex hull is given by a polygon with extreme data points as vertices. This is easiest to demonstrate graphically. In Figure 2 the convex hull is the smallest convex set that contains the data. ${ }^{8}$ Intuitively, counterfactuals outside the convex hull of the observed data are generally farther away from the data. More precisely, counterfactual "what if" questions that appear inside the polygon involve interpolation. On the contrary, counterfactual questions that appear outside the polygon require extrapolation and will therefore be sensitive to at least some modelling choices that are not based on empirical evidence. In other words, calculating the convex hull provides a natural check of the "distance" from the data,

\footnotetext{
${ }^{8}$ The convex-hull estimator of a boundary or frontier is also a cornerstone of any "'data envelope analysis" (DEA).
} 
thereby alerting one to the dangers of counterfactuals which require extrapolation. ${ }^{9}$ Figure 2 provides a diagrammatic illustration of this point.

Figure 2: The Convex Hull for Two Explanatory Variables

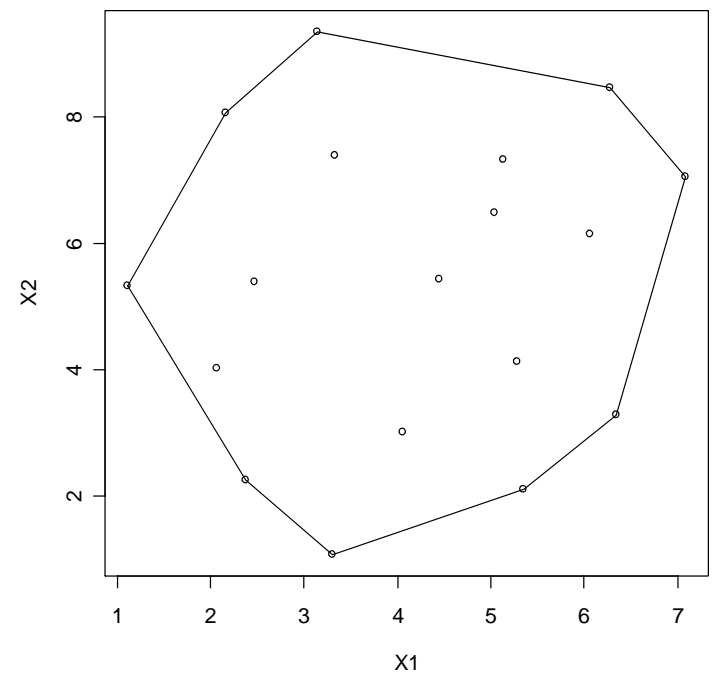

Although Figure 2 portrays the convex hull concept for the two dimensional case, the concept is well-defined for any number of dimensions. For three dimensions, the concept hull is calculated via "shrink mapping". For more than three dimensions, the concept is difficult to visualize, but the mathematical concept is straightforward. ${ }^{10}$

In a nutshell, what the convex hull methodology offers is an easy-to-apply method that reveals whether or not model dependence is present without having to run many alternative models. It applies to nearly every class of model whether they are estimated or not, conditional only on the choice of a given set of explanatory variables. If an analysis fails the convex hull test, i.e. a counterfactual falls outside the convex hull of the data, then we know that it will fail other sensitivity tests too, but we avoid having to estimate a large number of alternative models. ${ }^{11}$

\footnotetext{
${ }^{9}$ Models are typically written "globally", i.e. for any value of the explanatory variable. However, the models are only relevant "locally", i.e. nearby the observed data. One may therefore say that the convex hull methodology allows to determine where "local" ends and "global" begins. Ho et al (2007, p. 13), for example, have proposed to drop all observations that are outside of the convex hull before estimating the model.

${ }^{10}$ In computational geometry, numerous algorithms have been proposed for computing the convex hull of a finite set of points, with various computational complexities. Barber et al. (1997) have demonstrated that Qhull works efficiently in 2 to 8 dimensions (see http://www.qhull.org/). Our estimates below are based upon the What If program which offers easy-to-apply methods to evaluate counterfactuals. The suggested algorithm eliminates the most time-consuming part of the problem: the characterization of the convex hull itself. In addition, the remaining (implicit) point location problem can be expressed as a linear programming exercise, making it possible to take advantage of existing algorithms designed for other purposes to speed up the computation. See Stoll et al. (2006).

${ }^{11}$ Sala-i-Martin (1997), for example, has run two million regressions to identify robust relationships in the economic growth literature.
} 
The convex hull criterion leads to a qualitative 1/0-decision. Complementary, we therefore measure "distance" between two observations with a quantitative measure. Note that "distance" is a measure of similarity between observations in the multivariate space defined by the entire dataset. In order to determine the amount of data "nearby" the counterfactual, King and Zeng (2006, p. 137) have proposed a rule of thumb based upon the data's geometric variability and "distance from the data" measured using the Gower metric. ${ }^{12}$ The Gower distance measure provides quantitative information about "nearness", i.e. it provides a metric on which the accuracy of policy conclusions can be assessed. Only counterfactuals that have a distance from the data that is smaller than the data's geometric variability are deemed "nearby". This leads to a purposeful discussion of the potential uses of empirical growth estimates in policy discussions.

Following Gower $(1966,1971)$, the distance between two points $x_{i}$ and $x_{j}$ is measured according to

$$
G_{i j}^{2}=\frac{1}{K} \sum_{k=1}^{K} \frac{\left|x_{i k}-x_{j k}\right|}{r_{k}},
$$

where $K$ is the length of the vector $x$ and $r_{k}$ is the range of the data. Gower's distance is one of the most popular measures of proximity for mixed data types. It allows one to calculate for each counterfactual, $x$, the fraction of observations that is nearby $X$. If $G^{2}=0$, then $x$ and the row of $X$ in question are identical, and the larger $G_{i j}^{2}$, the more different the two rows are. An interesting feature is that the measure can be interpreted as the proportion of the distance across the data. For example, $G^{2}=0.5$ means that to get from one point to the other, one needs to travel $50 \%$ of the way across the dataset. Intuitively, any $G^{2}>1$ falls outside the convex hull of $X$. We can sum up the argument in this section by noting that the Gower distance measure enables us to distinguish between different shades of "nearness". This feature makes the Gower distance approach a helpful complement to the dichotomous convex hull criterion described above.

The next section summarizes the findings of various counterfactual simulations using the convex hull methodology, and discusses their use in economic growth analysis.

\section{Counterfactual Simulations}

To anchor our results in the existing growth literature, we draw on the Vamvakidis (2002) dataset. Vamvakidis (2002) has presented historical evidence of the openness-growth nexus. The dataset consists of repeated country cross-sections for the periods 1920-1940, 1950-1970, and 1970-1990. Besides average GDP per capita growth and various trade openness measures, the dataset also

${ }^{12}$ The geometric variability is also referred to as squared generalized standard deviation or generalized 
contains several other macro variables like initial GDP, the investment share, population growth, enrollment rates, inflation and the black market premium. In order to measure trade openness, Vamvakidis (2002) has tested six distinct approaches: the Sachs and Warner (1995) openness dummy, the average tariff rate, the average non-tariff barrier from the Barro and Lee dataset, the ratio of import duty revenues to total imports, the average trade share and the average trade share PPP adjusted (1970-1990 period). Out of these six measures only the Sachs and Warner (1995) openness dummy and the average trade share turned out to be robust in an extreme-bounds analysis. ${ }^{13}$ Furthermore, the results indicate that openness had a significant effect on growth after 1970 but not before. The size of the coefficients indicates that open economies have grown, on average, by 1.5-2.0 percentage points per year faster than closed economies. Given these estimation results, we use the 1970-1990 subsample for our empirical analysis below. ${ }^{14}$ Furthermore, we consider only the two robust openness measures.

The obvious question is how valuable is this kind of estimation result for the design of policy? Armed with this data and the convex hull methodology, we conduct various counterfactual experiments. Consistent with the philosophy of the endeavour, the experiments we choose should evaluate the importance of openness for growth. Specifically, we ask the question "what would happen if African countries were more open?".

Several counterfactual experiments are constructed. Counterfactual $A$ considers the growth implications of an increase of the trade share to the average level of $(i)$ the 24 high-income OECD countries, (ii) the EU-15 countries or (iii) the Asian countries in the dataset. These scenarios are referred to as $\mathrm{A}(\mathrm{OECD}), \mathrm{A}($ Europe), and $\mathrm{A}(\mathrm{Asia})$, respectively. Counterfactual $B$ takes into account that some African countries already have a higher trade share than the corresponding comparative value. In scenario B we therefore only consider those countries that actually "improve" their degree of openness. The values of all other variables are assumed to remain at their actual values. ${ }^{15}$

The details of our calculations are straightforward. First, we evaluate whether or not a certain country's counterfactual falls in the convex hull spanned by the dataset. Second, we determine the average portion of the data that is "nearby" the counterfactual. In Table 1 we present the empirical results for the counterfactual experiments.

Viewing the data through this prism, several clear-cut results emerge. In the specification without the investment share (specification I), only four African countries (Madagascar, Tunisia, Zambia and Zimbabwe) are located inside the convex hull. This number is even smaller for scenarios B and C.

variance, see Cuadras and Fortina (1995) and Cuadras et al. (1997).

${ }^{13}$ See Vamvakidis (2002) pp. 62-64 for a detailed description of the dataset and the estimation results. The WhatIf-software does not allow for NA's. We therefore only consider countries without data gaps.

${ }^{14}$ The sample consists of 152 countries, 46 of which are African. Vamvakidis (2002) distinguishes two model specifications, one excluding and one including the investment share as explanatory variable, see columns (9) and (10) in Table 1, p. 63. Both specifications are considered here, referred to as Specification I and II.

${ }^{15}$ Therefore, the counterfactual analysis is subject to the Lucas (1976) critique, in that the experiments proceed by changing sets of model parameters while holding others constant. 
Evaluating the complementary distance rule of thumb shows that the average portion of data nearby the counterfactual is, for all scenarios, greater for countries that fall inside the convex hull of the data: for instance, 0.34 for the "in hull", and 0.24 for the "not in hull" countries in the A(Asia)experiment. Similar results emerge from model specification II, see the lower panel of Table 2, but the number of "in hull" countries is even smaller. ${ }^{16}$

Table I: Evaluating Alternative Counterfactuals about Africa's Trade Openness

\begin{tabular}{|c|c|c|c|c|c|c|}
\hline & \multicolumn{6}{|c|}{ Specification I } \\
\hline Scenario & $\mathrm{A}(\mathrm{OECD})$ & $\mathrm{A}(\mathrm{EU}-15)$ & A(Asia) & $\mathrm{B}(\mathrm{OECD})$ & $\mathrm{B}(\mathrm{EU}-15)$ & B(Asia) \\
\hline $\begin{array}{l}\text { No. of } \\
\text { Countries }\end{array}$ & 30 & 30 & 30 & 20 & 24 & 24 \\
\hline $\begin{array}{l}\text { No. of } \\
\text { Countries } \\
\text { "In Hull" }\end{array}$ & 4 & 4 & 4 & 2 & 3 & 3 \\
\hline Countries & $\begin{array}{c}\text { Madagascar, } \\
\text { Tunisia, Zambia, } \\
\text { Zimbabwe }\end{array}$ & $\begin{array}{c}\text { Madagascar, } \\
\text { Tunisia, Zambia, } \\
\text { Zimbabwe }\end{array}$ & $\begin{array}{c}\text { Madagascar, } \\
\text { Tunisia, Zambia, } \\
\text { Zimbabwe }\end{array}$ & $\begin{array}{c}\text { Madagascar, } \\
\text { Tunisia }\end{array}$ & $\begin{array}{l}\text { Madagascar, } \\
\text { Tunisia, } \\
\text { Zimbabwe }\end{array}$ & $\begin{array}{c}\text { Madagascar, } \\
\text { Tunisia, } \\
\text { Zimbabwe }\end{array}$ \\
\hline $\begin{array}{l}\text { Average \% } \\
\text { of Data } \\
\text { „Nearby“ } \\
\text { (In Hull } \\
\text { only) }\end{array}$ & 0.35 & 0.35 & 0.34 & 0.39 & 0.37 & 0.36 \\
\hline $\begin{array}{c}\text { Average \% } \\
\text { of Data } \\
\text { „Nearby“ } \\
\text { (Not in Hull } \\
\text { only) }\end{array}$ & 0.25 & 0.25 & 0.24 & 0.27 & 0.26 & 0.25 \\
\hline & \multicolumn{6}{|c|}{ Specification II } \\
\hline Scenario & $\mathrm{A}(\mathrm{OECD})$ & $\mathrm{A}(\mathrm{EU}-15)$ & A(Asia) & $\mathrm{B}(\mathrm{OECD})$ & $\mathrm{B}(\mathrm{EU}-15)$ & B(Asia) \\
\hline $\begin{array}{c}\text { No. of } \\
\text { Countries }\end{array}$ & 30 & 30 & 30 & 20 & 24 & 24 \\
\hline $\begin{array}{c}\text { No. of } \\
\text { Countries } \\
\text { "In Hull" }\end{array}$ & 2 & 1 & 1 & 1 & 1 & 1 \\
\hline Countries & $\begin{array}{c}\text { Tunisia, } \\
\text { Zimbabwe }\end{array}$ & Tunisia & Tunisia & Tunisia & Tunisia & Tunisia \\
\hline $\begin{array}{l}\text { Average \% } \\
\text { of Data } \\
\text { „Nearby“ } \\
\text { (In Hull } \\
\text { only) }\end{array}$ & 0.33 & 0.30 & 0.33 & 0.34 & 0.30 & 0.33 \\
\hline $\begin{array}{l}\text { Average \% } \\
\text { of Data } \\
\text { „Nearby“ } \\
\text { (Not in Hull } \\
\text { only) }\end{array}$ & 0.20 & 0.20 & 0.20 & 0.22 & 0.21 & 0.21 \\
\hline
\end{tabular}

Notes: In both specifications, the trade share has been used as the openness measure. Specification I (II) has been estimated without (with) the investment share as an explanatory variable. Other regressors include initial income, secondary school enrollment, population growth, inflation and the black market premium. See Vamvakidis (2002), p. 63.

${ }^{16}$ Qualitatively identical results were obtained for the Sachs and Warner (1995) openness dummy variable. All of these excercises using the dichotomous openness measure give qualitatively identical results to those using the continuous trade openness measure. Thus, the results are not driven by some unusual feature of our data. Interested readers may obtain these supplementary results upon request. 
The straightforward interpretation arising from Table 1 is that the counterfactuals are not based in factual evidence since the countries under consideration do not share a common support. For most African countries the distance from the counterfactual to the data is too large and therefore the question posed cannot be reliably answered. Unfortunately, this conclusion is at odds with the literature arguing that greater openness unequivocally gives room for growth in Africa. ${ }^{17}$

By way of example, the presentation of the numerical convex hull results is now complemented by considering two further graphical representations of the results for scenario A(Asia). For ease of interpretation, Figure 3's categorical boxplot shows that the portion of "nearby data" for the four "in hull” countries (Madagascar, Tunisia, Zambia and Zimbabwe) are above the "not in hull” countries' median.

\section{Figure 3: Distribution of "Nearby" Data for "In Hull” vs. "Not In Hull” Countries}

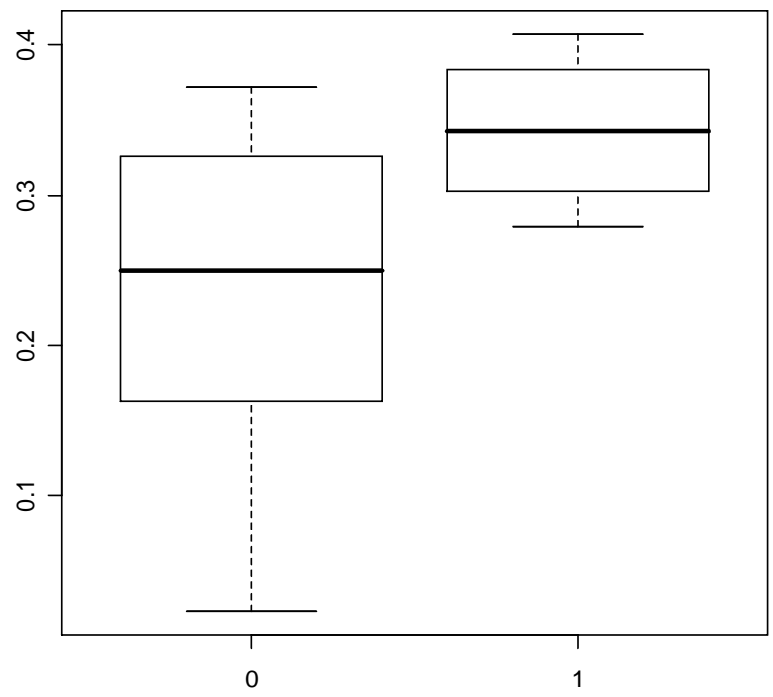

Note: The plot has been produced for specification I, i.e. without the investment share as an additional explanatory variable.

Finally, to aid in the interpretation of the results Figure 4 displays four cumulative frequency plots of the Gower distances, each of which compares one of the four "in hull" countries Madagascar, Tunisia, Zambia, and Zimbabwe to "not in hull" Gambia. Each line gives the cumulative distribution

${ }^{17}$ One might argue that this finding is consistent with the view that economic performance across former African colonies is still influenced by different types of initial conditions that the European powers encountered. In Sub-Saharan African colonies where settler mortality was high, extractive institutions designed to transfer rents to Europeans emerged. Such institutions did not create effective property rights, they did not generate incentives for investment, education and innovation, and they consequently retarded economic growth. Since institutions have a tendency to persist, this led to different paths during the critical junctures facing these former colonies. stayed in relative poverty. See Acemoglu et al. (2001, 2002). 
of the Gower distance measure. It is apparent that the four "in hull" countries generally have a larger portion of the data within a given distance.

\section{Figure 4: Cumulative Frequency Plots of the Gower Distances}
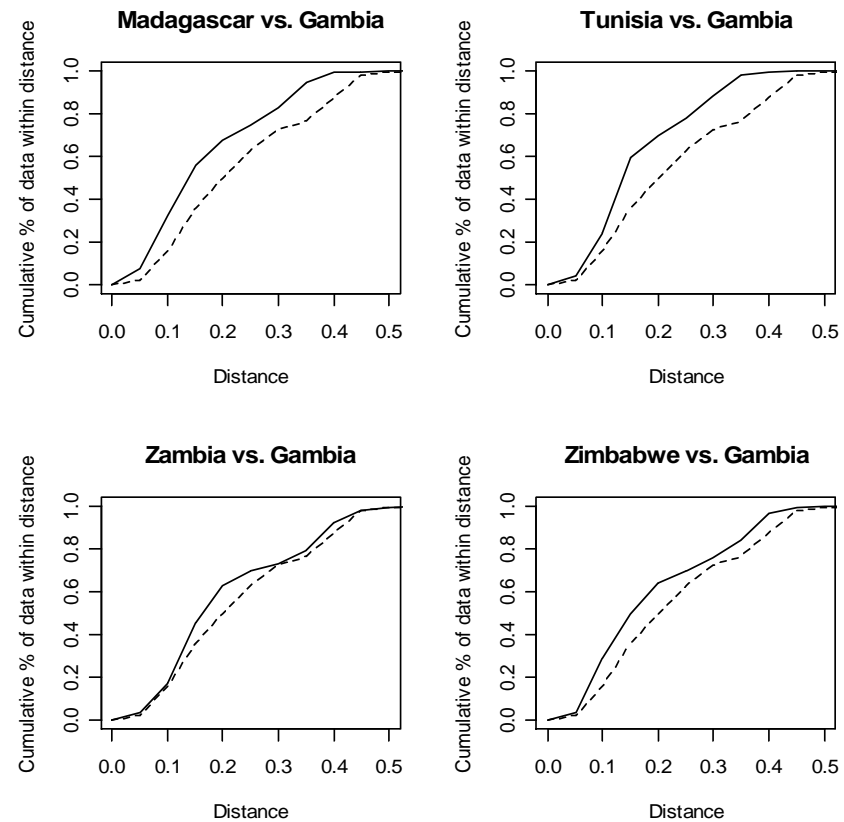

Note: Gower distances to five counterfactuals, Scenario A(Asia): Cumulative frequencies of Gower distances. Solid lines indicate "in hull", dashed lines "not in hull" countries.

To summarize, this analysis provides sufficient grounds for concluding that inference from the three counterfactual scenarios considered here is highly model dependent. Thus, caution should be employed in interpreting counterfactuals about trade openness and growth. In essence, trade openness itself seems to be no simple blueprint for success.

One way to assess the reasonability of our estimates is by looking at how stable are our convex hull estimates. Schrot (2007) and Sambanis and Michaelides (2009) have recently warned that the predictions of the convex hull approach may heavily rely on the econometric specification and could fail delivering sensible numbers. In particular, Sambanis and Michaelides (2009) have demonstrated using Monte Carlo experiments that as the number of variables $(k)$ grows and/or the number of observations $(n)$ declines, the convex hull diagnostics may lead researchers to infer that the data are likely to suffer from a high risk of extrapolation bias although this does not have to be true. Therefore they conclude that the convex hull diagnostics calculated above may provide too conservative for data sets in economics and political science. This small sample size $n / k$ problem encountered in the convex hull methodology is due to the complex geometry of multidimensional space and raises concerns about how confident we can be in the counterfactual analysis presented 
above. ${ }^{18}$ There is a simple way to examine whether we face this problem in the data: we carefully inspect the robustness of the results to changes in the set of conditioning variables.

Much economic research has been devoted in recent years to determining the set of explanatory variables that explain cross-country variation in growth rates. In an influential paper, Levine and Renelt (1992) have employed a variation of extreme bounds analysis to test the robustness of conventional growth regression coefficients to changes in the set of conditioning variables. They conclude that the results in the literature are rather fragile, with the only robust determinants of growth being physical capital investment, initial income, secondary school enrollment and openness. In contrast, they demonstrate the fragility of a host of fiscal and monetary variables, as well as measures of political and economic stability and economic distortions. Given their results and the $n / k$ problem mentioned above, we have finally re-estimated the convex hull diagnostics for this smaller set of conditioning variables. The results indicate that the assignment of countries inside or outside the convex hull is sensitive to the $n / k$ problem. For the A(OECD) scenario we find that 12 countries are inside the convex hull of the multi-dimensional space defined by the variables (Cameroon, Congo Republic, Gambia, Guinea-Bissau, Kenya, Marocco, Nigeria, Senegal, South Africa, Tunisia, Zambia, Zimbabwe), while 18 countries remain outside the hull (Algeria, Botswana, Burkina Faso, Burundi, Central African Republic, Chad, Egypt, Gabon, Ghana, Madagascar, Malawi, Mauritania, Mozambique, Niger, Rwanda, Sierra Leone, Togo, Uganda). ${ }^{19}$

The corresponding boxplots in Figure 5 are insightful. The countries of common support are characterised by a higher trade share, a higher investment ration, a higher initial GDP per capita and a higher school enrollment rate. ${ }^{20}$ The results discussed here suggest that a fruitful avenue for applied research and a good counterfactual rule of thumb therefore is to consider only the 12 more advanced economies for counterfactual policy simulations.

\footnotetext{
${ }^{18}$ Sambanis and Michaelides (2009) demonstrate that the small sample $n / k$ problem is most pronounced in data sets with a mix of binary and continuous variables.

${ }^{19}$ In unreported estimates we have reduced the number of regressors further to $k=2$ (initial income and openness). The number of countries inside the hull remains the same providing confidence about the results. Interested readers may obtain these supplementary results upon request.

${ }^{20}$ Equality of means tests indicate significant differences between both groups.
} 
Figure 3: Distribution of Data for "In Hull” (A) vs. "Not In Hull” (B) Countries

Trade Share

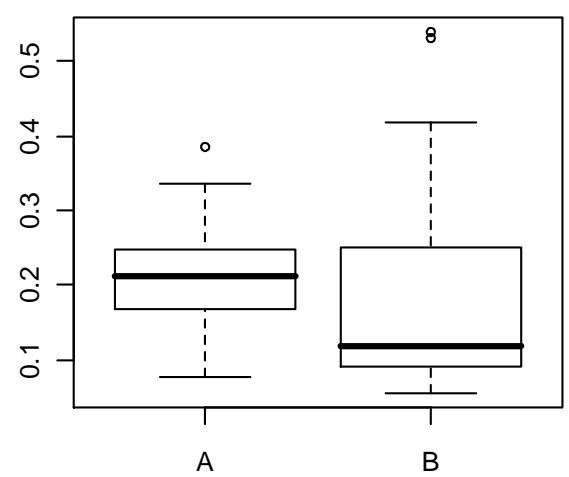

Initial GDP per capita

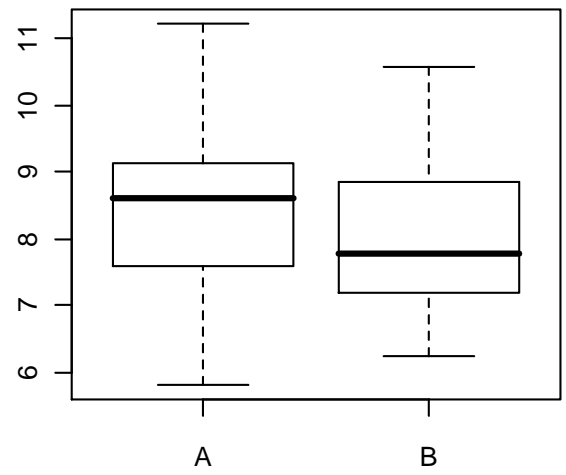

Investment Ratio

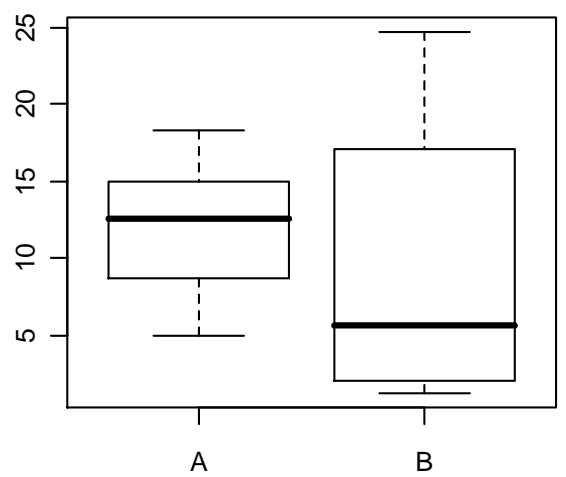

Secondary School Enrollment

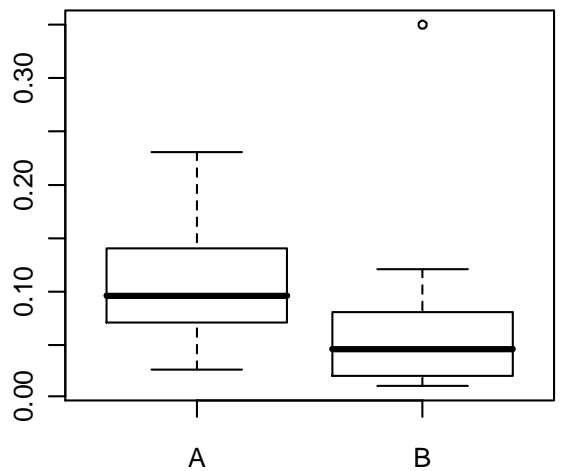

\section{Confronting the Numerical Underpinnings with Empirical Data}

Modelling exercises of the type presented in this paper are usually done in order to analyse the effects of a hypothetical policy reform. In our "what if" case, however, we are able to consider the impact of actual reforms since many African countries have embarked on programs of external economic liberalization in the 1990s. Has the convex hull classification any bearing on what is actually happening in the real world?

Hence, it is natural to present some empirical evidence about the effects of such policies for the 12 in-hull vs. the 18 out of hull countries as a robustness check. Is there empirical evidence to support the in hull vs. out of hull classification presented above? Unfortunately, the connection between trade and growth rates is hard to prove empirically and the exact definition of openness remains a matter of some dispute. Trade can be restricted in numerous ways, from quotas and tariffs to less obvious measures, such as capital controls. A careful measure of trade liberalization needs to 
quantify all these restrictions. To get an accurate picture, we employ the trade liberalization data from Warcziarg and Welch (2008). More precisely, we have ascertained for all 30 African countries in our dataset the year whether and when uninterrupted openness began in the 1990s.

The question whether or not one economic variable can help forecast another economic variable frequently arises in time series analysis and Granger causality tests have proven to be useful in this regard. Testing for Granger-causality involves using $F$-tests to test whether lagged information on a variable $X$ provides any statistically significant information about a variable $Y$ in the presence of lagged $Y$. If not, then " $X$ does not Granger-cause $Y$ ". There are several ways in which to implement a test of Granger causality. On particularly simple approach uses the autoregressive specification of a bivariate vector autoregression.

There are a few remarks to be made. First, in this study the sample size varies from country to country depending upon the timing of trade liberalization. Second, prior to estimation, one has to specify the number of lags. This is a crucial step because the causality test results may depend critically on the lag structure. In general, both too few and too many lags may cause problems. Too few lags will usually cause bias in the retained regression coefficients, leading to incorrect conclusions. On the other hand, too many lags waste observations. In our estimates, we pre-tested for the appropriate lag length using the Schwartz Criterion. Third, we have used first log-differences of both series.

We have divided the 30 African countries into those 12 countries which have reformed policy to qualify as "open" and those 18 countries which have followed protectionist and inward-looking economic policies in the 1990s according to Wacziarg and Welch's (2008) dichotomous trade policy indicator. Their in-depth work has been very influential, and this is our best estimate of the date for the onset of reforms. The regression results for the 12 African countries which have implemented programs of external economic liberalization in the 1990s are shown in Table 2.

Table 2: Bivariate Granger Causality Tests of the Openness-Growth Nexus

\begin{tabular}{|l|c|c|}
\hline & Year Uninterrupted Openness Began & Prob-Value \\
\hline In-Hull Countries & & \\
\hline Cameroon & 1993 & 0.0634 \\
\hline Kenya & 1993 & 0.1116 \\
\hline South Africa & 1991 & 0.7866 \\
\hline Zambia & 1993 & 0.0057 \\
\hline Not-in-Hull Countries & & \\
\hline Burkina Faso & 1998 & 0.0993 \\
\hline Burundi & 1999 & 0.1187 \\
\hline Egypt & 1995 & 0.9920 \\
\hline Madagascar & 1996 & 0.1446 \\
\hline Mauritania & 1995 & 0.2806 \\
\hline Mozambique & 1995 & 0.1469 \\
\hline Niger & 1994 & 0.7406 \\
\hline Sierra Leone & 2001 & 0.8885 \\
\hline
\end{tabular}


Notes: $\mathrm{H}_{0}$ : Openness does not cause GDP. As a measure of openness, we use the ratio of total trade to GDP. The original real GDP and trade share data have been extracted from the World Bank's World Development Indicators database. The country-specific timing of trade liberalization has been obtained from Wacziarg and Welch (2008), Table A-2.

What do the findings suggest? The important message of the Granger causality tests is that, if anything, trade liberalization had only Granger-caused growth in one out of eight "out of hull" countries at the 10 percent level. On the contrary, two out of four "in hull" countries have witnessed a fresh GDP spurt after trade liberalization at the 10 percent level. ${ }^{21}$

So what can a policymaker learn from the econometric results? Although certainly far from definitive, the lesson is nevertheless striking: Only inside the convex hull, freer trade has helped African countries to grow faster. This is suggestive - though limited in number of countries and observations - that the convex hull classification of countries provides useful insights and helps to unmask differences across countries. All in all, this finding advises against premature counterfactual exercises and cautions against one-size-fits-all policies that disregard country-specific circumstances. $^{22}$

\section{Summary and Some Concluding Thoughts}

Economists have long postulated that openness may raise growth. Despite this great deal of credence in the modern growth literature, however, some deep scepticism has developed regarding the robustness of the links between openness and growth. For example, in the excellent survey by Hallak and Levinsohn (2007), the authors identify three major shortcomings in the cross-country evidence. First, openness is typically summarized by a one-dimensional index that has little theoretical foundation. Second, there are several omitted variables biases, which lead to results which are not robust. Finally, there is so much heterogeneity in economic conditions across countries that it is doubtful that there is a unique mapping of openness into economic growth. ${ }^{23}$

This paper proposes a method for thinking about whether or not a counterfactual analysis is meaningful. The convex hull method is quite intuitive: if the counterfactual "what if" scenario lies outside the convex hull of the data, this must mean that the counterfactual will be predominantly driven by the model rather than the data. In other words, predictions will be sensitive to the assumptions the researcher makes. We explain the method and then provide an example of why

\footnotetext{
${ }^{21}$ Expansion in the continent's largest economy, South Africa, has been boosted by the ongoing construction and investment boom as preparations for the 2010 football World Cup gather momentum.

${ }^{22}$ Sachs and Warner (1997) have suggested that openness to international trade had an impact upon growth across African countries. However, their evidence suggests that part of Africa's slow growth also lies with natural factors such as being landlocked, natural resource abundance, and tropical climate.

${ }^{23}$ Policymakers and researchers face considerable uncertainty given a set of multiple, overlapping theories which emphasize different growth channels. Brock and Durlauf (2001) refer to this as „open-endedness“ of economic theories, in the sense that one theory being true does not necessarily imply another one is wrong.
} 
researchers need to be cautious in conducting counterfactual analysis. The counterfactual example asks what would happen to Africa's growth should African countries liberalize their trade regimes. ${ }^{24}$ The straightforward interpretation emanating from this paper is that the counterfactuals are not based in factual evidence since many countries under consideration do not share a common support. For 18 African countries the distance from the counterfactual to the data is too large and therefore the question posed cannot be reliably answered.

From a methodological perspective, deep scepticism has been brought to bear against empirical cross-country evidence on the trade-growth nexus. Therefore, economists and policymakers face a formidable problem. We conclude from the exercise that it is important to check for the existence of common support across countries. In fact, the advantage of a convex hull analysis lies in the simple guidance for appropriately restricting policy conclusions to specific subsamples. It should therefore becomes an integral part of the sensitivity testing toolbox of applied economists in the future. Overall, the results recommend refraining from commenting on the potential effect of greater trade openness on growth in most African countries in the 1990s in an unconditional way. ${ }^{25}$

We have presented a number of pieces of evidence that we hope will stimulate others to use the convex hull methodology in the future and pursuing this debate further. We hope that is what we have accomplished here.

Furthermore, within each theoretical channel there may be multiple competing measures representing the same theory.

${ }^{24}$ The question is similar to current debates in the development literature on whether or not we can generalize facts learned from randomized experiments. While a program intervention may be successful in one setting, it may not be in other settings [see Rodrik (2008)].

${ }^{25}$ This conclusion is, for example, consistent with Rodriguez and Rodrik (2001). They have found evidence for the hypothesis that trade openness isn't associated with economic growth unlimited as regards substance, space and time. In particular, they have argued that the Sachs-Warner (1995) results largely reflected the black market premium and the state monopoly on major exports. The Wacziarg and Welch (2008) results on shifts in trade policy and outward orientation in the 1990s used above have addressed this critique. 


\section{References:}

Acemoglu, D., Johnson, S. and Robinson, J.A. (2001) "The Colonial Origins of Comparative Development: An Empirical Investigation", American Economic Review 91, 1369-1401.

Acemoglu, D., Johnson, S. and Robinson, J.A. (2001) "Reversal of Fortune: Geography and Institutions in the Making of the Modern World Income Distribution", Quarterly Journal of Economics 118, 1231-1294.

Barber, C. B., Dobkin, D. P. and H.T. Huhdanpaa (1997) "The Quickhull Algorithm for Convex Hulls", ACM Trans. Mathematical Software 22, 469-483.

Billmeier, A. and T. Nannicini (2007) "Trade Openness and Growth: Pursuing Empirical Glasnost", IMF Working Paper No. WP/07/156, Washington.

Brock, W.A. and S.N. Durlauf (2001) "Growth Empirics and Reality", The World Bank Economic Review 15, 229-272.

Cuadras, C.M. and J. Fortiana (1995) "A Continuous Metric Scaling Solution for a Random Variable", Journal of Multivariate Analysis 52, 1-14

Cuadras, C.M., J. Fortiana and F. Oliva (1997) "The Proximity of an Individual to a Population with Applications to Discriminant Analysis”, Journal of Classification 14, 117-136

De Berg, M., van Kreveld, M., Overmars, M. and O. Schwarzkopf (2000) Computational Geometry: Algorithms and Applications, $2^{\text {nd }}$ edition, Heidelberg/New York (Springer).

Easterly, W. and R. Levine (1997) "Africa's Growth Tragedy: Policies and Ethnic Divisions", Quarterly Journal of Economics 112, 1203-1250.

Gower, J.C. (1966) "Some Distance Properties of Latent Root and Vector Methods Used in Multivariate Analysis", Biometrika 53, 325-388

Gower, J.C. (1971) “A General Coefficient of Similarity and Some of Its Properties”, Biometrics 27, 857-872

Hallak, J.C. and J. Levinsohn (2007) "Fooling Ourselves: Evaluating the Globalization and Growth Debate", in: Zedillo, E. (ed.) The Future of Globalization: Explorations in Light of Recent Turbulence, London/New York (Routledge), 209-223.

Hausmann, R. and D. Rodrik (2003) "Economic Development as Self-Discovery", Journal of Development Economics 72, 603-33.

Ho, D.E,, Imai, K., G. King and E.A. Stuart (2007) "Matching as Nonparametric Proprocessing for reducing Model Dependence in Parametric Causal Inference", Political Analysis 15, 199-236.

King, G. and L. Zeng (2006) “The Dangers of Extreme Counterfactuals”, Political Analysis 14, 131159.

King, G. and L. Zeng (2007) "When Can History Be Our Guide? The Pitfalls of Counterfactual Inference", International Studies Quarterly 51, 183-210.

Levine, R. and D. Renelt (1992) "A Sensitivity Analysis of Cross-country Growth Regressions", American Economic Review 82, 942-963. 
Lucas, R. (1976) "Econometric Policy Evaluation: A Critique", Journal of Monetary Economics, Supplementary Series 1, 19-46.

Rodriguez, F. and D. Rodrik (2001) "Trade Policy and Economic Growth: A Sceptics Guide to the Cross-National Evidence", in: Bernanke, B. and K. Rogoff (eds.) NBER Macroeconomics Annual $15,261-325$.

Rodrik, D. (2006) “What's So Special about China's Exports?”, China \& World Economy 14, 1-19.

Rodrik, D. (2008) "Second-Best Insitutions", NBER Working Papers No. 14050, Cambridge (Mass.).

Sachs, J.D. and A. Warner (1995) "Economic Reform and the Process of Global Integration", Brooking Papers of Economic Activity, Issue 1, 1-95.

Sachs, J.D. and A.W. Warner (1997) "Sources of Slow Growth in African Economies", Journal of African Economies 6, 335-376.

Sala-i-Martin, X. (1997) “I Just Ran Two Million Regressions”, American Economic Review 87, 178-183.

Schott, P. (2006) "The Relative Sophistication of Chinese Exports", NBER Working Paper No. 12173, Cambridge (Massachusetts).

Schrodt, P.A. (2007) "Of Dinosaurs and Barbecue Sauce: A Comment on King and Zeng", International Studies Quarterly 51, 211-215.

Sambanis, N. and A. Michaelides (2009) "A comment on diagnostic Tools for Counterfactual Inference", Political Analysis (forthcoming).

Stoll, H., G. King and L. Zeng (2006) "WhatIf: R Software for Evaluating Counterfactuals", Journal of Statistical Software 15, Issue 4, 1-18.

Temple, J. (2000) "Growth Regressions and What the Textbooks Don't Tell You", Bulletin of Economic Research 52, 181-205.

Vamvakidis, A. (2002) "How Robust is the Growth Openness Connection? Historical Evidence", Journal of Economic Growth 7, 57-80.

Wacziarg, R. and K.H. Welch (2008) “Trade Liberalization and Growth: New Evidence”, The World Bank Economic Review 22, 187-231.

Worldbank (1993) The East Asian Miracle, Washington. 


\section{CESifo Working Paper Series}

for full list see www.cesifo-group.org/wp

(address: Poschingerstr. 5, 81679 Munich, Germany, office@cesifo.de)

2629 Håkan Selin, The Rise in Female Employment and the Role of Tax Incentives - An Empirical Analysis of the Swedish Individual Tax Reform of 1971, April 2009

2630 Nick Johnstone and Ivan Hascic, Environmental Policy Design and the Fragmentation of International Markets for Innovation, April 2009

2631 Spiros Bougheas, Richard Kneller and Raymond Riezman, Optimal Education Policies and Comparative Advantage, April 2009

2632 Jay Pil Choi and Heiko Gerlach, Multi-Market Collusion with Demand Linkages and Antitrust Enforcement, April 2009

2633 Thor O. Thoresen, Income Mobility of Owners of Small Businesses when Boundaries between Occupations are Vague, April 2009

2634 Guido Schwerdt and Amelie C. Wuppermann, Is Traditional Teaching really all that Bad? A Within-Student Between-Subject Approach, April 2009

2635 Kurt R. Brekke, Luigi Siciliani and Odd Rune Straume, Hospital Competition and Quality with Regulated Prices, April 2009

2636 Peter Diamond, Taxes and Pensions, April 2009

2637 Shoshana Grossbard, How "Chicagoan" are Gary Becker's Economic Models of Marriage?, May 2009

2638 Roland Strausz, Regulatory Risk under Optimal Incentive Regulation, May 2009

2639 Holger Zemanek, Ansgar Belke and Gunther Schnabl, Current Account Imbalances and Structural Adjustment in the Euro Area: How to Rebalance Competitiveness, May 2009

2640 Harald Hau and Marcel Thum, Subprime Crisis and Board (In-)Competence: Private vs. Public Banks in Germany, May 2009

2641 Martin Halla, Mario Lackner and Friedrich G. Schneider, An Empirical Analysis of the Dynamics of the Welfare State: The Case of Benefit Morale, May 2009

2642 Balázs Égert, Infrastructure Investment in Network Industries: The Role of Incentive Regulation and Regulatory Independence, May 2009

2643 Christian Gollier, Expected Net Present Value, Expected Net Future Value, and the Ramsey Rule, May 2009

2644 Sören Blomquist and Håkan Selin, Hourly Wage Rate and Taxable Labor Income Responsiveness to Changes in Marginal Tax Rates, May 2009 
2645 Dominique Demougin, Oliver Fabel and Christian Thomann, Implicit vs. Explicit Incentives: Theory and a Case Study, May 2009

2646 Francesco C. Billari and Vincenzo Galasso, What Explains Fertility? Evidence from Italian Pension Reforms, May 2009

2647 Kjell Arne Brekke, Karen Evelyn Hauge, Jo Thori Lind and Karine Nyborg, Playing with the Good Guys - A Public Good Game with Endogenous Group Formation, May 2009

2648 Guglielmo Maria Caporale and Luis A. Gil-Alana, Multi-Factor Gegenbauer Processes and European Inflation Rates, May 2009

2649 Henning Bohn, A Static Model for Voting on Social Security, May 2009

2650 Markus Haavio and Kaisa Kotakorpi, The Political Economy of Sin Taxes, May 2009

2651 Augusto de la Torre, María Soledad Martínez Pería and Sergio L. Schmukler, Drivers and Obstacles to Banking SMEs: The Role of Competition and the Institutional Framework, May 2009

2652 Tobias Lindhe and Jan Södersten, Dividend Taxation, Share Repurchases and the Equity Trap, May 2009

2653 Assaf Razin and Edith Sand, Migration-Regime Liberalization and Social Security: Political-Economy Effect, May 2009

2654 Yin-Wong Cheung and Hiro Ito, A Cross-Country Empirical Analysis of International Reserves, May 2009

2655 Bart Cockx and Bruno Van der Linden, Flexicurity in Belgium. A Proposal Based on Economic Principles, May 2009

2656 Michael Melvin, Lukas Menkhoff and Maik Schmeling, Exchange Rate Management in Emerging Markets: Intervention via an Electronic Limit Order Book, May 2009

2657 Susanne Neckermann, Reto Cueni and Bruno S. Frey, What is an Award Worth? An Econometric Assessment of the Impact of Awards on Employee Performance, May 2009

2658 Steven Brakman, Harry Garretsen and Charles van Marrewijk, Economic Geography within and between European Nations: The Role of Market Potential and Density across Space and Time, May 2009

2659 Giovanni Facchini and Cecilia Testa, Reforming Legislatures: Is one House better than two?, May 2009

2660 Carsten Kowalczyk and Raymond Riezman, Trade Agreements, May 2009 
2661 Oliver Falck, Stephan Heblich and Elke Luedemann, Identity and Entrepreneurship, May 2009

2662 Christian Lessmann and Gunther Markwardt, One Size Fits All? Decentralization, Corruption, and the Monitoring of Bureaucrats, May 2009

2663 Felix Bierbrauer, On the Legitimacy of Coercion for the Financing of Public Goods, May 2009

2664 Alessandro Cigno, Agency in Family Policy: A Survey, May 2009

2665 Claudia M. Buch and Christian Pierdzioch, Low Skill but High Volatility?, May 2009

2666 Hendrik Jürges, Kerstin Schneider, Martin Senkbeil and Claus H. Carstensen, Assessment Drives Learning: The Effect of Central Exit Exams on Curricular Knowledge and Mathematical Literacy, June 2009

2667 Eric A. Hanushek and Ludger Woessmann, Schooling, Cognitive Skills, and the Latin American Growth Puzzle, June 2009

2668 Ourania Karakosta, Christos Kotsogiannis and Miguel-Angel Lopez-Garcia, Does Indirect Tax Harmonization Deliver Pareto Improvements in the Presence of Global Public Goods?, June 2009

2669 Aleksandra Riedl and Silvia Rocha-Akis, Testing the Tax Competition Theory: How Elastic are National Tax Bases in OECD Countries?, June 2009

2670 Dominique Demougin and Carsten Helm, Incentive Contracts and Efficient Unemployment Benefits, June 2009

2671 Guglielmo Maria Caporale and Luis A. Gil-Alana, Long Memory in US Real Output per Capita, June 2009

2672 Jim Malley and Ulrich Woitek, Productivity Shocks and Aggregate Cycles in an Estimated Endogenous Growth Model, June 2009

2673 Vivek Ghosal, Business Strategy and Firm Reorganization under Changing Market Conditions, June 2009

2674 Francesco Menoncin and Paolo M. Panteghini, Retrospective Capital Gains Taxation in the Real World, June 2009

2675 Thomas Hemmelgarn and Gaëtan Nicodème, Tax Co-ordination in Europe: Assessing the First Years of the EU-Savings Taxation Directive, June 2009

2676 Oliver Himmler, The Effects of School Competition on Academic Achievement and Grading Standards, June 2009

2677 Rolf Golombek and Michael Hoel, International Cooperation on Climate-Friendly Technologies, June 2009 
2678 Martin Cave and Matthew Corkery, Regulation and Barriers to Trade in Telecommunications Services in the European Union, June 2009

2679 Costas Arkolakis, A Unified Theory of Firm Selection and Growth, June 2009

2680 Michelle R. Garfinkel, Stergios Skaperdas and Constantinos Syropoulos, International Trade and Transnational Insecurity: How Comparative Advantage and Power are Jointly Determined, June 2009

2681 Marcelo Resende, Capital Structure and Regulation in U.S. Local Telephony: An Exploratory Econometric Study; June 2009

2682 Marc Gronwald and Janina Ketterer, Evaluating Emission Trading as a Policy Tool Evidence from Conditional Jump Models, June 2009

2683 Stephan O. Hornig, Horst Rottmann and Rüdiger Wapler, Information Asymmetry, Education Signals and the Case of Ethnic and Native Germans, June 2009

2684 Benoit Dostie and Rajshri Jayaraman, The Effect of Adversity on Process Innovations and Managerial Incentives, June 2009

2685 Peter Egger, Christian Keuschnigg and Hannes Winner, Incorporation and Taxation: Theory and Firm-level Evidence, June 2009

2686 Chrysovalantou Milliou and Emmanuel Petrakis, Timing of Technology Adoption and Product Market Competition, June 2009

2687 Hans Degryse, Frank de Jong and Jérémie Lefebvre, An Empirical Analysis of Legal Insider Trading in the Netherlands, June 2009

2688 Subhasish M. Chowdhury, Dan Kovenock and Roman M. Sheremeta, An Experimental Investigation of Colonel Blotto Games, June 2009

2689 Alexander Chudik, M. Hashem Pesaran and Elisa Tosetti, Weak and Strong Cross Section Dependence and Estimation of Large Panels, June 2009

2690 Mohamed El Hedi Arouri and Christophe Rault, On the Influence of Oil Prices on Stock Markets: Evidence from Panel Analysis in GCC Countries, June 2009

2691 Lars P. Feld and Christoph A. Schaltegger, Political Stability and Fiscal Policy - Time Series Evidence for the Swiss Federal Level since 1849, June 2009

2692 Michael Funke and Marc Gronwald, A Convex Hull Approach to Counterfactual Analysis of Trade Openness and Growth, June 2009 